\title{
ASUPAN KALSIUM, STATUS GIZI, TEKANAN DARAH DAN HUBUNGANNYA DENGAN KELUHAN SENDI LANSIA DI PANTI WERDHA BANDUNG
}

\author{
(Calcium Intake, Nutritional Status, Blood Pressure, and Relationship to Joint Pain among \\ Elderly in Nursing Homes in Bandung City)
}

\author{
Nining Tyas Triatmaja ${ }^{1 *}$, Ali Khomsan ${ }^{1}$, dan Mira Dewi ${ }^{1}$
}

'Departemen Gizi Masyarakat, Fakultas Ekologi Manusia (FEMA), Institut Pertanian Bogor, Bogor 16680

\begin{abstract}
The objective of this study was to determine the relationship of calcium intake, nutritional status, and blood pressure to joint pain among elderly in nursing homes in Bandung. The study design was cross-sectional study. Subjects were consisted of 12 elderly men and 69 elderly women from four nursing homes in Bandung. Most subjects had joint pain (59.3\%), hypertension (30.9\%), and were overweight (39.5\%). There was no significant relationship between frequency of consumption of calcium food sources and nutritional status, blood pressure, joint pain, and the level of joint pain $(p>0.05)$. There was no significant relationship between joint pain and the level of joint pain with blood pressure and nutritional status.
\end{abstract}

Keywords: blood pressure, calcium, elderly, joint pain, nutritional status

\begin{abstract}
ABSTRAK
Penelitian ini bertujuan untuk mengetahui hubungan asupan kalsium, status gizi, dan tekanan darah terhadap keluhan sendi pada lansia di Panti Werdha Kota Bandung. Desain penelitian ini adalah cross-sectional. Subjek terdiri atas 12 lansia pria dan 69 lansia wanita dari empat panti werdha di Kota Bandung. Sebagian besar subjek mempunyai keluhan sendi (59.3\%), hipertensi (30.9\%), dan status gizi overweight (39.5\%). Tidak terdapat hubungan yang signifikan antara frekuensi konsumsi pangan sumber kalsium dengan status gizi, tekanan darah, keluhan sendi, dan tingkat keluhan sendi $(p>0.05)$. Tidak terdapat hubungan yang signifikan antara keluhan sendi dan tingkat keluhan sendi dengan tekanan darah dan status gizi.
\end{abstract}

Kata kunci: kalsium, keluhan sendi, lansia, status gizi, tekanan darah

"Korespondensi: Departemen Gizi Masyarakat, Fakultas Ekologi Manusia (FEMA), Institut Pertanian Bogor, Bogor 16680. Email: niningtyastriatmaja@gmail.com 


\section{PENDAHULUAN}

Salah satu dampak dari keberhasilan pembangunan nasional di bidang kesehatan dan kesejahteraan sosial antara lain meningkatnya angka rata-rata usia harapan hidup penduduk yang ditandai dengan makin bertambahnya jumlah lansia. Lansia mengalami penurunan kondisi tubuh yang merupakan bagian dari proses penuaan. Semakin bertambahnya usia maka akan lebih mudah terserang berbagai penyakit degeneratif. Salah satu penyakit degeneratif yang sering diderita lansia adalah penyakit sendi. Laporan Riset Kesehatan Dasar (Riskesdas) tahun 2007 menyatakan bahwa prevalensi nasional penyakit sendi adalah $30.3 \%$ dan prevalensi berdasarkan diagnosis tenaga kesehatan adalah 14\% (Depkes 2008).

Penyakit sendi yang sering diderita oleh lansia adalah osteoarthritis (radang sendi). Sebanyak 17.82\% lansia berusia $>50$ tahun di Yunani menderita osteoarthritis (Anagnostopoulos et al. 2010). Penyakit sendi umumnya ditandai dengan keluhan-keluhan terkait sendi. Penyakit atau keluhan sendi yang diderita oleh lansia dapat disebabkan oleh beberapa faktor. Salah satunya adalah berat badan. Asokan et al. (2011) menyatakan bahwa sebanyak 50\% lansia wanita di Bahrain dengan status gizi obesitas dan $30 \%$ dengan status gizi overweight menderita osteoarthritis. Kejadian penyakit atau keluhan sendi dari segi gizi dikaitkan dengan kebiasaan konsumsi kalsium yang berhubungan dengan diet seseorang. Menurut Duncan (2004), penderita osteoarthritis kurang mengonsumsi produk olahan susu, kalsium, dan vitamin D. Hipertensi merupakan faktor risiko lain yang memengaruhi kejadian penyakit atau keluhan sendi pada lansia. Sebanyak 13\% lansia wanita di Bahrain yang menderita osteoarthritis mempunyai tekanan darah tinggi (hipertensi) (Asokan 2011).

Peningkatan prevalensi penyakit atau keluhan sendi pada lansia memerlukan perhatian dan penanganan yang tepat. Salah satu penanganan terhadap lansia adalah melalui wadah panti werdha. Berdasarkan hal-hal tersebut maka peneliti tertarik untuk melakukan penelitan tentang konsumsi kalsium, status gizi, tekanan darah, dan hubungannya terhadap keluhan sendi pada lansia di panti werdha Kota Bandung. Pemilihan Kota Bandung sebagai lokasi penelitian adalah karena Kota Bandung terletak di Provinsi Jawa Barat yang merupakan salah satu provinsi dengan prevalensi penyakit sendi di atas prevalensi nasional, yaitu 41.4\% (Depkes 2008). Selain itu, Kota Bandung merupakan salah satu kota besar di Indonesia yang mempunyai panti werdha dalam jumlah yang banyak dengan manajemen panti yang baik.

Secara umum penelitian ini bertujuan untuk mengetahui hubungan konsumsi kalsium, status gizi, dan tekanan darah terhadap keluhan sendi pada lansia di panti werdha Kota Bandung. Tujuan khusus penelitian ini adalah menganalisis frekuensi konsumsi pangan sumber kalsium, menganalisis status gizi, tekanan darah, keluhan sendi, aktivitas kehidupan sehari-hari (activity daily living), persepsi status kesehatan dan persepsi rasa nyeri, tingkat keluhan sendi, serta menganalisis hubungan konsumsi kalsium, status gizi dan tekanan darah dengan keluhan sendi pada lansia di Panti werdha Kota Bandung.

\section{METODE}

\section{Desain, Tempat, dan Waktu}

Penelitian ini merupakan bagian dari penelitian yang berjudul Studi tentang Status Gizi, Karakteristik Kesehatan, dan Aspek Psikososial Lansia yang Tinggal dengan Keluarga dan di Panti Werdha, yang diketuai oleh Rita Patriasih S.Pd, M.Si. Penelitian ini menggunakan desain cross sectional. Lokasi penelitian adalah Panti Sosial Tresna Werdha (PSTW) Budi Pertiwi, PSTW Senjarawi, PSTW Laswi, dan Wisma Lansia Ny. J. Soenarti Nasution. Penelitian ini dilakukan pada bulan Juli 2012.

\section{Jumlah dan Cara Penarikan Subjek}

Subjek yang diambil adalah subjek yang memenuhi kriteria inklusi, yaitu lansia berusia $\geq 55$ tahun, mampu makan menggunakan mulut, tidak ada bagian tubuh yang diamputasi sehingga tidak membutuhkan koreksi berat badan untuk bagian tubuh yang hilang, tinggal di panti werdha, dapat berkomunikasi dengan baik, tidak mempunyai gangguan ingatan, tidak mempunyai gangguan pendengaran dan bersedia diwawancara sebagai subjek. Jumlah lansia yang tinggal di keempat panti secara keseluruhan berjumlah 171 orang sedangkan yang memenuhi kriteria inklusi dan menjadi subjek adalah 81 orang.

\section{Jenis dan Cara Pengumpulan Data}

Data karakteristik subjek diperoleh melalui wawancara langsung dengan menggunakan kuesioner. Frekuensi konsumsi pangan sumber kalsium subjek dilakukan dengan wawancara menggunakan instrumen FFQ (Food Frequency Questionnaire). Data konsumsi pangan subjek diperoleh dengan wawancara menggunakan Food Recall 2x24 jam. Status gizi dinilai menggunakan pengukuran antropometri yang meliputi berat badan, lingkar lengan atas, dan tinggi lutut. Penilaian keluhan sendi dilakukan dengan menggunakan kuesioner RAPID3 (routine assessment of patient index data). Data gambaran umum panti diperoleh dengan melakukan wawancara kepada pengurus panti, pengamatan langsung, dan data sekunder. 


\section{Pengolahan dan Analisis Data}

Karakteristik individu. Umur subjek dikelompokkan menurut Departemen Kesehatan Republik Indonesia, yaitu kelompok usia lanjut dini (55-64 tahun), kelompok usia lanjut (lebih dari 65 tahun), dan usia lanjut lebih dari 70 tahun. Jenis kelamin subjek dikategorikan menjadi dua, yaitu laki-laki dan perempuan. Pendidikan subjek dikategorikan menjadi lima berdasarkan ijazah terakhir subjek, yaitu tidak sekolah, SD, SMP, SMA, dan perguruan tinggi. Pekerjaan subjek dikategorikan menjadi lima, yaitu tidak bekerja, pedagang, buruh, petani, dan lainnya. Status pernikahan dikategorikan menjadi tiga, yaitu menikah, janda/duda, dan tidak menikah. Pendapatan subjek dikategorikan menjadi empat dengan menghitung angka standar pendapatan terlebih dahulu. Angka standar pendapatan diperoleh dengan menggunakan rumus (Pendapatan maksimal-pendapatan minimal). Kemudian pendapatan subjek dibagi menjadi empat, yaitu (1) tidak mempunyai pendapatan, (2) (angka pendapatan minimal+1) s/d angka standar pendapatan, (3) (angka standar pendapatan +1 ) s/d (angka standar pendapatan $+($ angka standar pendapatan +1$))$, (4) (angka standar pendapatan+(angka standar pendapatan +1) )+1 s/d pendapatan maksimal. Pendapatan subjek dikategorikan menjadi empat, yaitu Rp 0, Rp 1-Rp 1333 333, Rp 1333 334-Rp 2666 667, dan Rp 2666 668-Rp 4000000.

Frekuensi konsumsi pangan sumber kalsium. Kebiasaan konsumsi pangan sumber kalsium dikelompokkan menjadi: 1) tidak pernah jika subjek tidak mengonsumsi pangan sumber kalsium selama satu bulan, 2) $\leq 3 x$ dalam seminggu, 3 ) $>3 x$ dalam seminggu, 4) $\geq 1 x$ dalam sehari.

Status gizi. Tinggi badan lansia diprediksi dengan menggunakan tinggi lutut. Fatmah et al. (2008) merekomendasikan model prediksi tinggi badan lansia, yaitu: 1) Laki-laki: Prediksi $T B=56.343+2.102$ tinggi lutut, 2) Perempuan: Prediksi TB=62.682+1.889 tinggi lutut. Estimasi berat badan berdasarkan ukuran lingkar lengan atas menggunakan rumus sebagai berikut 1) Laki-laki: Prediksi $B B=2.592 L L A-12.902$, 2) Perempuan: Prediksi $B B=2.001$ LLA-1.223. Status gizi diukur dinilai dengan menggunakan IMT, dengan rumus Berat Badan $(\mathrm{kg}) /(\text { Tinggi Badan }(\mathrm{m}))^{2}$. Penggolongan status gizi menggunakan cut off point IMT pada tahun 2005 menurut WHO (Gibson 2005).

Tekanan darah. Tekanan darah subjek dibedakan menjadi dua, yaitu normal dan hipertensi berdasarkan cut off JNC-7.

Keluhan sendi. Penilaian tingkat keluhan sendi dilakukan dengan menggunakan kuesioner RAPID3 yang terdiri dari tiga komponen yaitu activity daily living, persepsi status kesehatan, dan persepsi rasa nyeri sendi (Pincus et al. 2009). Activity daily living dinilai dengan cara subjek diminta memilih jawaban dari pernyataan aktivitas harian sesuai dengan kondisi subjek. Pilihan jawaban terdiri atas 0) tanpa kesulitan, 1) sulit, 2) banyak kesulitan, dan 3) tidak dapat melakukan. Skor kesepuluh jawaban dijumlahkan. Jumlah skor 0-30 dikonversikan menjadi skor 0-10. Penilaian persepsi status kesehatan dan persepsi rasa nyeri dengan cara subjek diminta untuk memberikan jawaban atas status kesehatan dan rasa nyeri yang dirasakan subjek saat wawancara dengan memilih skala visual antara skala 0-10. Persepsi rasa nyeri hanya untuk subjek yang mengalami keluhan sendi sedangkan activity daily living dan persepsi status kesehatan ditanyakan ke semua subjek. Tingkat keluhan sendi dibedakan menjadi tinggi, sedang, rendah, dan lemah.

Uji korelasi Spearman digunakan untuk mengetahui hubungan antara frekuensi konsumsi pangan sumber kalsium dengan status gizi, tekanan darah, dan tingkat keluhan sendi, hubungan antara status gizi dan tekanan darah dengan tingkat keluhan sendi, dan hubungan antara usia dan keluhan sendi. Uji korelasi Chi-square digunakan untuk mengetahui ada tidaknya hubungan antara keluhan sendi dengan frekuensi konsumsi pangan sumber kalsium, hipertensi, dan status gizi. Uji Mann-Whitney digunakan untuk mengetahui perbedaan keluhan sendi antara subjek wanita dan subjek pria.

\section{HASIL DAN PEMBAHASAN}

\section{Karakteristik Subjek}

Jumlah subjek lansia wanita (85.2\%) di empat panti lebih banyak daripada subjek lansia pria (14.8\%). Hal ini disebabkan ada satu panti yang semua penghuninya adalah perempuan. Sebagian besar subjek (53.0\%) berada pada kelompok usia $\geq 70$ tahun. Rata-rata lama pendidikan subjek adalah $6.6 \pm 4.8$ tahun. Sebanyak $43.2 \%$ subjek tidak bersekolah dan hanya $7.4 \%$ subjek yang menamatkan pendidikan sampai perguruan tinggi.

Rata-rata pendapatan subjek adalah Rp 413 $913 \pm R p 762$ 954. Pendapatan minimal subjek adalah Rp 0 sedangkan pendapatan maksimal subjek adalah Rp 4000 000. Sebagian besar subjek tidak bekerja saat ini $(86.4 \%)$. Status pernikahan subjek saat ini sebagian besar adalah janda/duda (66.7\%). Sebagian besar subjek yang tidak menikah merupakan lansia wanita (32.1\%).

\section{Frekuensi Konsumsi Pangan Sumber Kalsium}

Subjek diwawancarai beberapa jenis pangan sumber kalsium, yaitu bayam, teri, tempe, tahu, daun singkong, dan susu. Pemilihan pangan tersebut 
Tabel 1. Sebaran Subjek menurut Frekuensi Konsumsi Pangan Sumber Kalsium

\begin{tabular}{lcccccccc}
\hline \multirow{2}{*}{ Pangan } & \multicolumn{2}{c}{ Tidak pernah } & \multicolumn{3}{c}{$\leq 3 \times$ seminggu } & \multicolumn{2}{c}{$>$ 3x seminggu } & \multicolumn{2}{c}{$\geq 1$ x sehari } \\
\cline { 2 - 10 } & $\mathrm{n}$ & $\%$ & $\mathrm{n}$ & $\%$ & $\mathrm{n}$ & $\%$ & $\mathrm{n}$ & $\%$ \\
\hline Bayam & 33 & 40.7 & 48 & 59.3 & 0 & 0.0 & 0 & 0.0 \\
Teri & 51 & 63.0 & 30 & 37.0 & 0 & 0.0 & 0 & 0.0 \\
Tempe & 2 & 2.5 & 21 & 25.9 & 12 & 14.8 & 46 & 56.8 \\
Tahu & 1 & 1.2 & 21 & 25.9 & 11 & 13.6 & 48 & 56.8 \\
Daun singkong & 61 & 75.3 & 20 & 24.7 & 0 & 0.0 & 0 & 0.0 \\
Susu & 36 & 44.4 & 24 & 29.6 & 1 & 1.2 & 20 & 24.5 \\
\hline
\end{tabular}

didasarkan pada kandungan kalsium jenis pangan tersebut. Sebaran subjek menurut frekuensi konsumsi pangan sumber kalsium disajikan pada Tabel 1.

Pangan yang selalu dikonsumsi subjek setiap harinya adalah tempe dan tahu. Hal ini disebabkan panti selalu menyediakan tempe atau tahu sebagai lauk pauk setiap harinya. Sebanyak $24.5 \%$ subjek mengonsumsi susu setiap hari. Namun, terdapat 44.4\% subjek yang tidak pernah mengonsumsi susu. Teri merupakan pangan yang banyak tidak dimakan oleh subjek. Sebanyak $63.0 \%$ subjek tidak mengonsumsi ikan teri sedangkan sisanya $(37.0 \%)$ hanya mengonsumsi teri dengan frekuensi kurang dari $3 x$ dalam seminggu. Pangan lainnya yang banyak tidak dimakan oleh subjek adalah daun singkong dan bayam. Alasan subjek jarang mengonsumsi daun singkong dan bayam adalah karena panti jarang menyediakan daun singkong dan bayam sebagai menu makanan.

\section{Konsumsi Pangan}

Konsumsi pangan harian subjek di panti berasal dari makanan panti dan makanan luar panti. Makanan panti terdiri dari makanan utama yang diberikan sebanyak tiga kali dalam sehari dan makanan selingan yang diberikan sebanyak satu kali dalam sehari. Rata-rata tingkat kecukupan energi subjek berada dalam kategori normal. Rata-rata konsumsi energi subjek, yaitu 1324 kkal masih berada di bawah rata-rata konsumsi energi lansia di PSTW Budi Mulia 4 Jakarta yaitu 1490 kkal (Jauhari 2003). Sturm et al. (2004) menyatakan bahwa konsumsi energi lansia di Adelaide lebih rendah jika dibandingkan dengan konsumsi energi selain lansia. Proses penuaan dapat menekan rasa lapar dengan mekanisme pelebaran daerah antral dan peningkatan kadar kolesitokinin dalam plasma.

Rata-rata konsumsi protein subjek, yaitu $32 \mathrm{~g}$ masih berada di bawah rata-rata konsumsi protein orang Indonesia, yaitu $55.5 \mathrm{~g} /$ hari (Depkes 2008). Rendahnya rata-rata konsumsi protein subjek disebabkan subjek kurang mengonsumsi pangan hewani yang merupakan sumber protein utama. Konsumsi protein yang rendah berhubungan dengan penurunan densitas mineral tulang (Rapuri et al. 2003).

Konsumsi zat gizi lainnya yang dinilai adalah kalsium. Rata-rata konsumsi kalsium subjek selama dua hari adalah $571 \mathrm{mg}$. Rata-rata konsumsi kalsium subjek lebih tinggi daripada rata-rata konsumsi kalsium lansia di PSTW Budi Mulia 4 Jakarta yaitu 457.7 mg (Jauhari 2003). Namun, rata-rata konsumsi kalsium subjek lebih rendah daripada konsumsi kalsium lansia di Australia, yaitu $955 \mathrm{mg} /$ hari (Devine et al. 2005). Rendahnya konsumsi kalsium subjek disebabkan kurangnya subjek dalam mengonsumsi pangan hewani yang merupakan sumber kalsium utama seperti susu dan ikan teri.

\section{Status Gizi}

Sebagian besar subjek (39.5\%) mempunyai status gizi overweight. Sebanyak $16.0 \%$ subjek mempunyai status gizi obesitas 1 dan sebanyak 3.7\% subjek mempunyai status gizi obesitas 2 . Penelitian status gizi lansia juga dilakukan terhadap lansia di daerah Pennsylvania. Hasil penelitian tersebut yaitu sebanyak $44 \%$ subjek mempunyai status gizi overweight dan $35 \%$ subjek mempunyai status gizi obesitas (Ledikwe et al. 2003).

Selain terdapat subjek yang mempunyai status gizi lebih dan obesitas, juga terdapat subjek yang mempunyai status gizi kurus. Sebanyak $11.1 \%$ subjek mempunyai status gizi kurus dan sebanyak $2.5 \%$ subjek mempunyai status gizi sangat kurus. Namun berbeda dengan penelitian yang dilakukan oleh Ledikwe et al. (2003) yang menyatakan bahwa tidak terdapat lansia di daerah Pennsylvania yang mempunyai status gizi underweight. Status gizi kurang pada lansia dapat terjadi karena kurangnya konsumsi pangan lansia akibat penurunan nafsu makan pada lansia.

\section{Tekanan Darah}

Hasil penelitian ini menunjukkan bahwa sebanyak $30.9 \%$ subjek mengalami hipertensi. Hipertensi pada lansia juga dapat dinyatakan dalam hasil penelitian Jauhari (2003), yaitu sebanyak 28.3\% lansia di Panti Werdha Budi Mulia 4 Jakarta mengalami 
hipertensi. Ledikwe et al. (2003) juga menyatakan bahwa sebanyak 50\% lansia di Pennsylvania berusia $\geq 65$ tahun menderita hipertensi. Tingginya kasus hipertensi pada lansia dapat dipengaruhi oleh faktor umur. Widyaningsih dan Latifah (2008) menyatakan bahwa setiap kenaikan usia satu tahun maka tekanan darah sistolik akan meningkat sebesar $0.369 \mathrm{mmHg}$ dan sebesar $0.283 \mathrm{mmHg}$ untuk tekanan darah diastolik. Peningkatan tekanan darah pada lansia juga diduga karena kurangnya aktivitas fisik pada subjek. Salah satu faktor utama penyebab hipertensi adalah kurangnya aktivitas fisik (JNC-7 2003).

\section{Keluhan Sendi}

Keluhan sendi subjek dalam penelitian ini ditentukan dengan menanyakan ada tidaknya keluhan yang dialami oleh subjek yaitu berupa nyeri sendi. Sebagian besar subjek dalam penelitian ini mempunyai keluhan sendi (59.3\%), yaitu berupa rasa nyeri. Keluhan atau nyeri sendi banyak dialami oleh lansia. Soeroso et al. (2005) menyatakan bahwa usia >50 tahun merupakan salah satu faktor risiko osteoarthritis lutut di Indonesia. Namun, berdasarkan uji korelasi Spearman tidak terdapat hubungan antara ada tidaknya keluhan sendi dengan usia subjek ( $p>0.05$; $r=0.015)$. Hal ini diduga karena tidak semua keluhan sendi yang dialami subjek akibat faktor usia. Beberapa subjek menyatakan bahwa keluhan sendi yang dirasakan oleh subjek adalah akibat terjatuh. Buchanan dan Kean (2002) menyatakan bahwa faktor usia bukan merupakan satu-satunya penyebab terjadinya osteoarthritis.

Keluhan sendi banyak dirasakan oleh subjek wanita daripada subjek pria. Sebanyak $89.6 \%$ subjek yang mempunyai keluhan sendi adalah subjek wanita. Penelitian Rosemann (2008) pada pasien osteoarthritis di Baden-Wuerttemberg dan Bavaria menyatakan bahwa sebanyak 66\% pasien osteoarthritis adalah wanita. Gandhi et al. (2010) menya- takan bahwa wanita lebih banyak menyimpan lemak di daerah ekstremitas bawah sehingga menyebabkan beban berlebih pada lutut. Uji Mann-Whitney menyatakan bahwa terdapat perbedaan ada tidaknya keluhan sendi yang signifikan antara subjek wanita dengan subjek pria.

Bentuk keluhan sendi yang dirasakan oleh subjek bermacam-macam antara lain, nyeri, kaku, sampai tidak bisa digerakkan. Sebanyak $50.6 \%$ subjek menyatakan bahwa keluhan sendi hanya dirasakan di satu bagian tubuh saja. Bagian tubuh yang sering dirasakan nyeri adalah lutut (33.3\%) dan kaki (12.4\%). Sebanyak $47 \%$ wanita di Bahrain menderita osteoarthritis lutut, $7 \%$ menderita osteoarthritis di pinggang dan osteoarthritis gabungan antara lutut dan pinggang menempati urutan pertama yaitu sebanyak 51\% (Asokan et al. 2011). Penyakit sendi sering memengaruhi sendi antar jari kaki, ibu jari, lutut, pinggang, pergelangan kaki, dan tulang belakang yang bekerja menopang berat badan (Duncan 2004). Lama waktu subjek dalam merasakan keluhan sendi bervariasi. Sebagian besar subjek (32.1\%) menyatakan bahwa subjek merasakan keluhan sendi selama $<1$ hari.

\section{Tingkat Keluhan Sendi}

Activity Daily Living (ADL). Subjek diminta menyebutkan kesan subjek dalam melakukan aktivitas dasar harian. Kesan tersebut terbagi menjadi empat, yaitu tidak mengalami kesulitan dalam melakukan, agak sulit dalam melakukan, sangat sulit dalam melakukan, dan tidak dapat melakukan. Sebaran subjek menurut activity daily living disajikan pada Tabel 2.

Minum dan memutar kran merupakan kegiatan yang paling banyak dapat dilakukan oleh subjek (97.5\%). Hal ini karena minum dan memutar kran merupakan kegiatan yang mudah dilakukan dan hanya melibatkan sendi-sendi pada jari-jari tangan.

Tabel 2. Sebaran Subjek menurut Aktivitas Sehari-hari (Activity Daily Living)

\begin{tabular}{lcccccccc}
\hline \multirow{2}{*}{ Kegiatan } & \multicolumn{2}{c}{ Tidak sulit } & \multicolumn{2}{c}{ Agak sulit } & \multicolumn{2}{c}{ Sangat sulit } & \multicolumn{2}{c}{$\begin{array}{c}\text { Tidak dapat } \\
\text { melakukan }\end{array}$} \\
\cline { 2 - 9 } & $\mathrm{n}$ & $\%$ & $\mathrm{n}$ & $\%$ & $\mathrm{n}$ & $\%$ & $\mathrm{n}$ & $\%$ \\
\hline Memakai pakaian sendiri & 76 & 93.8 & 3 & 3.7 & 1 & 1.2 & 1 & 1.2 \\
Turun naik tempat tidur & 76 & 93.8 & 4 & 4.9 & 0 & 0.0 & 1 & 1.2 \\
Minum & 79 & 97.5 & 2 & 2.5 & 0 & 0.0 & 0 & 0.0 \\
Jalan & 64 & 79.0 & 6 & 7.4 & 7 & 8.6 & 4 & 4.9 \\
Mandi & 75 & 92.6 & 2 & 2.5 & 1 & 1.2 & 3 & 3.7 \\
Menggantungkan baju & 67 & 82.7 & 5 & 6.2 & 5 & 6.2 & 4 & 4.9 \\
Memutar kran & 79 & 97.5 & 2 & 2.5 & 0 & 0.0 & 0 & 0.0 \\
Turun naik bis, mobil, kereta & 53 & 65.4 & 8 & 9.9 & 9 & 11.1 & 11 & 13.6 \\
Berjalan sejauh 1.5 km & 23 & 28.4 & 40 & 49.4 & 11 & 13.6 & 7 & 8.6 \\
Berolahraga & 64 & 79.0 & 5 & 6.2 & 8 & 9.9 & 4 & 4.9 \\
\hline
\end{tabular}


Kegiatan lainnya yang dapat dilakukan subjek tanpa kesulitan adalah memakai pakaian, turun naik tempat tidur, dan mandi. Kegiatan yang paling banyak tidak dapat dilakukan oleh subjek adalah kegiatan turun naik bis, mobil, atau kereta (13.6\%). Subjek yang tidak mampu melakukan kegiatan turun naik bis atau kereta merupakan subjek yang mempunyai keterbatasan dalam bergerak. Umumnya subjek dibantu menggunakan tongkat atau kursi roda dalam berjalan atau bergerak.

Sebanyak 49.4\% subjek menyatakan agak sulit jika berjalan sejauh $1.5 \mathrm{~km}$. Subjek menyatakan bahwa subjek lelah jika harus berjalan jauh. Beberapa subjek menyatakan bahwa lutut dan kakinya sakit jika berjalan jauh. Beberapa subjek lainnya menyatakan bahwa tidak pernah melakukan kegiatan jalan jauh. Sebanyak 79.0\% subjek menyatakan tidak mengalami kesulitan melakukan kegiatan jalan di sekitar panti. Namun terdapat empat orang yang tidak mampu berjalan. Kegiatan subjek yang tidak mampu berjalan hanya terbatas di tempat tidur. Olahraga yang dilakukan subjek adalah senam lansia. Sebagian besar subjek menyatakan tidak mengalami kesulitan dalam melakukan olahraga senam (79.0\%).

Persepsi Status Kesehatan. Persepsi status kesehatan subjek dibedakan menjadi tiga, yaitu baik, sedang, dan buruk. Sebagian besar subjek menyatakan bahwa status kesehatannya adalah baik (70.4\%). Subjek pada saat diwawancarai tidak dalam keadaan sakit dapat dikatakan status kesehatannya saat itu adalah baik. Subjek yang status kesehatannya tergolong sedang merupakan subjek yang pada saat diwawancarai dalam keadaan sakit namun tidak parah, misalnya subjek sedang batuk atau merasa badannya pegal-pegal, yaitu sebanyak 18.5\%. Subjek yang status kesehatannya buruk merupakan subjek yang pada saat diwawancarai sedang dalam keadaan sakit parah dan tidak mempunyai kemampuan untuk berjalan.

Persepsi Rasa Nyeri Sendi. Persepsi rasa nyeri yang dirasakan oleh subjek paling banyak adalah rasa nyeri hebat. Persepsi rasa nyeri hebat dirasakan oleh sebagian besar subjek (45.8\%). Umumnya nyeri hebat yang dirasakan oleh subjek bertahan lama dan akan sembuh setelah beberapa hari. Subjek yang mempunyai persepsi rasa nyeri ringan hanya merasakan nyeri di salah satu bagian tubuh saja. Subjek merasakan rasa nyeri hanya beberapa jam dan akan hilang dengan istirahat atau mengolesi bagian tubuh yang sakit dengan obat oles penghilang rasa nyeri. Rasa nyeri ringan dirasakan oleh sebagian kecil subjek (18.8\%).

Tingkat Keluhan Sendi. Tingkat keluhan sendi subjek dibedakan menjadi empat kategori, yaitu tinggi, sedang, rendah, dan lemah. Keluhan sendi dengan tingkat sedang dialami oleh sebagian besar subjek, yaitu sebanyak 38.3\%. Keluhan sendi dengan tingkat sedang dapat dialami oleh subjek yang mempunyai persepsi status kesehatan yang kurang baik karena subjek merasa kurang sehat saat diwawancarai. Subjek juga mempunyai persepsi rasa nyeri namun masih mampu melakukan kegiatan yang termasuk dalam activity daily living tanpa kesulitan. Subjek dengan tingkat keluhan sendi yang tinggi memerlukan penanganan dan perawatan yang lebih dibandingkan dengan tingkat keluhan sendi lainnya (23.5\%). Subjek dengan skor tingkat keluhan lemah mampu melakukan kegiatan yang termasuk dalam activity daily living, kecuali jalan kaki sejauh 1.5 km (14.8\%). Subjek tidak mempunyai keluhan sendi dan dalam keadaan sehat.

\section{Hubungan Beberapa Variabel}

Hasil korelasi Spearman menunjukkan bahwa frekuensi konsumsi kelima pangan sumber kalsium tidak berhubungan dengan status gizi. Berbeda dengan hasil studi yang dilakukan oleh Varenna et al. (2007) pada 1771 perempuan postmenopause yang menunjukkan bahwa konsumsi kalsium yang tinggi berhubungan terbalik dengan Indeks Massa Tubuh (IMT).

Frekuensi pangan sumber kalsium juga tidak berhubungan dengan tekanan darah $(p>0.05)$. Hal ini diduga ada faktor lain yang memengaruhi terjadinya hipertensi pada subjek seperti faktor usia. Kuswardhani (2006) dalam Widyaningsih dan Latifah (2008) menyatakan bahwa semakin tua seseorang maka pengaturan metabolisme kalsium terganggu sehingga banyak kalsium yang beredar bersama darah. Bertambahnya usia juga menyebabkan elastisitas pembuluh darah arteri berkurang sehingga volume darah yang mengalir sedikit dan kurang lancar.

Tidak terdapat hubungan yang signifikan antara frekuensi konsumsi pangan sumber kalsium dengan ada tidaknya penyakit sendi dan tingkat keluhan sendi $(p>0.05)$. Konsumsi kalsium dapat meningkatkan densitas massa tulang dan mencegah osteoporosis (Nieves 2005). Tidak terdapatnya hubungan yang signifikan diduga akibat kalsium tidak dapat bekerja dengan baik apabila tidak ada bantuan dari zat gizi mikro lain dalam pencegahan osteoporosis dan kaitannya dengan osteoarthritis. Nieves (2005) menyatakan bahwa kalsium dapat memberikan manfaat untuk massa tulang di semua umur, walaupun hasilnya tidak selalu konsisten.

Hipertensi dan status gizi tidak berhubungan dengan ada tidaknya keluhan sendi dan tingkat keluhan sendi. Studi yang dilakukan Jauhari (2003) pada lansia di Panti Werdha Budi Mulia 4 Jakarta menyatakan bahwa terdapat hubungan positif yang signifikan antara status gizi dan rematik $(p=0.05$; $r=0.27$ ). Adanya perbedaan hasil dengan penelitian 
sebelumnya diduga karena subjek kurang melakukan aktivitas berat seperti berjalan sehingga walaupun subjek mempunyai status gizi obesitas atau overweight, lutut subjek tidak mendapatkan beban berat dalam menopang tubuh.

\section{KESIMPULAN}

Pangan sumber kalsium yang selalu dikonsumsi subjek setiap harinya adalah tempe dan tahu. Sebanyak $24.5 \%$ subjek mengonsumsi susu setiap hari. Ikan teri, daun singkong, dan bayam jarang dikonsumsi oleh subjek. Sebagian besar subjek mempunyai status gizi overweight (39.5\%). Sebanyak $30.9 \%$ subjek mengalami hipertensi. Sebagian besar subjek dalam penelitian ini mempunyai keluhan sendi, yaitu berupa rasa nyeri (59.3\%).

Minum dan memutar kran merupakan kegiatan yang paling banyak dapat dilakukan oleh subjek. Kegiatan yang paling banyak tidak dapat dilakukan oleh subjek adalah kegiatan turun naik bis, mobil, atau kereta. Sebagian besar subjek menyatakan bahwa status kesehatannya adalah baik (70.4\%). Persepsi rasa nyeri yang dirasakan oleh subjek paling banyak adalah rasa nyeri hebat (45.8\%). Keluhan sendi dengan tingkat sedang dialami oleh sebagian besar subjek, yaitu sebanyak $38.3 \%$.

Frekuensi konsumsi kelima pangan sumber kalsium tidak berhubungan dengan status gizi, tekanan darah, keluhan sendi, dan tingkat keluhan sendi. Tidak terdapat hubungan yang signifikan antara hipertensi dan status gizi dengan ada tidaknya keluhan sendi dan tingkat keluhan sendi.

Konsumsi pangan sumber kalsium di kalangan lansia masih rendah. Susu yang merupakan sumber kalsium utama kurang dikonsumsi oleh lansia di panti werdha. Hal ini disebabkan kurang tersedianya susu di panti sehingga pihak panti sebaiknya menyediakan susu minimal satu minggu sekali. Penelitian selanjutnya diharapkan dapat mengidentifikasi keluhan sendi berdasarkan jenis penyakitnya.

\section{DAFTAR PUSTAKA}

Anagnostopoulos I et al. 2010. The prevalence of rheumatic diseases in central Greece: a population survey. BMC Muskuloskeletal Disoerders, 11,98.

Asokan GV et al. 2011. Osteoarthritis among women in Bahrain: a public health audit. Oman Medical Journal, 26(6), 426-430.

Buchanan WW \& Kean WF. 2002. Osteoarthritis I: Epidemiological risk factor and historical considerations Review. Inflammopharmacology, 10(1), 5-21.
[Depkes RI] Departemen Kesehatan Republik Indonesia. 2008. Laporan Riset Kesehatan Dasar Tahun 2007. Badan Penelitian dan Pengembangan Kesehatan Kementerian Kesehatan Republik Indonesia, Jakarta.

Devine A et al. 2005. Protein consumption is an important predictor of lower limb bone mass in elderly women. Am J Clin Nutr, 81,14231428.

Duncan K. 2004. Medical Nutrition Therapy for Rheumatic Disease. Di dalam: Mahan LK dan Escott Stump S, editor. Food, Nutrition and Diet Therapy $\mathrm{hlm}$ 1042-1061. Saunders co, USA.

Fatmah et al. 2008. Model prediksi tinggi badan lansia etnis jawa berdasarkan tinggi lutut, panjang depa, dan tinggi duduk. Majalah Kedokteran Indonesia, 58(12), 509-516.

Gandhi $\mathrm{R}$ et al. 2010. The relation between body mass index and waist-hip ratio in knee osteoarthritis. Can J Surg, 53(3), 151-154.

Gibson RS. 2005. Principles of Nutritional Assessment. Oxford University Press, New York.

Jauhari M. 2003. Status gizi, kesehatan dan kondisi mental lansia di Panti Sosial Tresna Werdha Budi Mulia 4 Jakarta [tesis]. Program Pascasarjana, Institut Pertanian Bogor, Bogor.

JNC-7. 2003. The Seventh Report of the Joint National Committee on Prevention, Detection, Evaluation, and Treatment of High Blood Pressure. JAMA 289, 2560-2571.

Kuswardhani T. 2006. Penatalaksanaan hipertensi pada lanjut usia. Jurnal Penyakit Dalam, 7, 135-140.

Ledikwe JH et al. 2003. Nutritional risk assessment and obesity in rural older adults: a sex difference. Am J Clin Nutr, 77, 551-558.

Nieves JW. 2005. Osteoporosis: the role of micronutrients. Am J Clin Nutr, 81, 1232-1239.

Pincus et al. 2009. RAPID3-An index of physical function, pain, and global status as"vital signs" to improve care for people with chronic rheumatic diseases. Bulletin of the NYU Hospital for Joint Diseases, 67(2), 211-225.

Rapuri PB et al. 2003. Protein intake:effects on bone mineral density and the rate of bone loss in elderly women. Am J Clin Nutr, 77, 1517-1525.

Rosemann T et al. 2008. Pain and osteoarthritis in primary care: Factor associated with pain perception in a sample of 1021 patients. Pain Medicine, 9(7), 1526-2357.

Soeroso et al. 2008. Risk factor of symptomatic osteoarthritis of the knee at a hospital in Indonesia. Journal of Rheumatology, 8, 106-113.

Sturm et al. 2004. Energy intake and appetite are 
Triatmaja dkk.

related to antral area in healthy young and older subjects. Am J Clin Nutr, 80, 656-667.

Varenna $M$ et al. 2007. Effects of dietary calcium

intake on body weight and prevalence of os- teoporosis in early postmenopausal women. American Journal Clinical Nutrition, 86, 639644. 